\title{
Evaluation of Enzyme Protease Activity and Inhibition Effect on Pyricularia grisea with the Leaf Extract of Commela communis $\mathrm{L}$.
}

\author{
Chau Thanh Truc, Pham Thi Thu Ha* (D), Nguyen Thi Ngoc Tram and Do Thi Duyen \\ Faculty of Applied Sciences, Ton Duc Thang University, Ho Chi Minh City, Vietnam.
}

\begin{abstract}
Rice blast is a dangerous disease that causes major damage to rice productivity worldwide. The purpose of this report is to examine the protease activity of Pyricularia grisea and the effects of Commelina communis $L$. (common name "day flower") extract on mycelial growth. The result showed that three isolates were collected from wild rice (Oryza rufipogon) based on a designation of new international standard and namely as U43-i4-k024-z05-ta532 (isolate 1); U12-i0-k101-z05-ta102 (isolate 2) and U43-i4-k141-z15-ta522 (isolate 3). Particularly, the third isolate showed the highest protease enzyme activity of $30.11 \mathrm{U} / \mathrm{ml}$, followed by isolate $1(20.27 \mathrm{U} / \mathrm{ml})$ and isolate $2(12.81 \mathrm{U} / \mathrm{ml})$. The new fungi isolated from wild rice may be important methods to control detrimental diseases infesting cultivated rice. The result showed methanol extract from the day flower inhibitions on P.grisea. Besides protease activity, fungi inhibition was also affected. The protease activity was low; the mycelial growth inhibition was high ( $\mathrm{IC}_{50}=2.35 \mathrm{mg} / \mathrm{mL}$ at Isolate 2 ). Plant extracts from the day flower saved money and were environmentally friendly. So the implementation of this substance is very essential.
\end{abstract}

Keywords: Protease activity, Pyricularia grisea, crude extract, antifungal activity, mycelial growth.

*Correspondence: phamthithuha@tdtu.edu.vn; +84933092584

(Received: 10 April 2019; accepted: 08 August 2019)

Citation: Chau Thanh Truc, Pham Thi Thu Ha, Nguyen Thi Ngoc Tram and Do Thi Duyen, Evaluation of Enzyme Protease Activity and Inhibition Effect on Pyricularia grisea with the Leaf Extract of Commela communis L., J Pure Appl Microbiol., 2019; 13(3): 1389-1396. https://doi.org/10.22207/JPAM.13.3.09

C The Author(s) 2019. Open Access. This article is distributed under the terms of the Creative Commons Attribution 4.0 International License which permits unrestricted use, sharing, distribution, and reproduction in any medium, provided you give appropriate credit to the original author(s) and the source, provide a link to the Creative Commons license, and indicate if changes were made. 


\section{INTRODUCTION}

Fungi play an important role in the area of microbiology and biochemistry because of their ability to produce useful enzymes (Bhat et al. 2013). In fact, fungal enzymes have been employed for the rapid oxidation and decomposition of proteins, carbohydrates, and fats (Portumarthi et al. 2017). Proteases are especially known to be enzyme catalysts that hydrolyse peptide bonds in proteins (Shakil et al. 2012, Hanan et al. 2012). They can be found in all forms of life including plants, animals, and micro-organisms. Proteases are classified into three groups based on their optimum $\mathrm{pH}$ for hydrolysis including acid, neutral and alkaline proteases (Khan et al. 2011). The presence of extracellular proteases have been reported in several fungal plant pathogens, and proteases produced by pathogenic fungi play an important role in host tissue invasion, providing nitrogenous compounds to fungus during infection (Chen et al. 1993). Patil et al. (2015) have successfully isolated endophytic fungi from seven different medicinal plants and evaluated for their enzymatic activities such as amylase, protease, cellulose, and lipase.

In recent years, there has been a suggestion that Pyricularia grisea Sacc (syn: Magnaporthe grisea (Hebert) Barr) is one of the most destructive fungi to the rice production industry in the world. In an attempt to reduce the damage caused by this fungus, the uses of many eco-friendly agrochemicals have recently drawn a lot of attention. For example, the extract of different plants such as Epicoccum sp., Prosophis juliflora, and Ziziphus are known to have the ability to inhibit mycelial growth of $P$. grisea (Kamalakannan et al. 2001, Sena et al. 2013). E. aromatica, $P$. guineense and $G$. kola extracts can also be used as biological fungicides against the development of $P$. grisea (Olufolaji et al. 2001). Several other trees were tested and showed $P$. grisea inhibition (Olufolaji et al. 2015, Netam et al. 2011). In other research, the composition of bamboo leaves containing compounds derived from hexane and ethyl acetate such as fatty acids, oils and phenols, and their derivatives minimize the growth of $P$. grisea (Toan et al. 2018).

The day flower, Commelina communis L., is distributed widely throughout the world. The whole plants have been used as a febrifuge or a diuretic in Japanese folk medicine. In addition, the plant is also known to contain potent $\alpha$-glucosidase inhibitors. These extracts and powders are also used as ingredients in the prevention of type 2 diabetes (Shibano et al. 2001). The alkaloid extracted from this plant was resistant to the virus A / PR / 8/34 (H1N1) (Fei-Hong Bing et al. 2009). However, the inhibitory effect of the leaf extract of Commela communis L. on P. grisea is still to be determined. Therefore, the purpose of this study is to examine: (1) the protease activity of fungal isolates, and (2) the fungi-inhibitory effects of Commelina communis L. extracts which may shed light on the new treatment methods of plant diseases in the agriculture-related field.

\section{MATERIALS AND METHODS Fungi source}

P.grisea is isolated from wild rice (Oryza rufipogon) collected from rice fields in south of Vietnam.

\section{Medium preparation}

The agar for monoclonal isolation includes glucose $(5 \mathrm{~g})$, yeast extract $(5 \mathrm{~g})$, agar $(30 \mathrm{~g})$, streptomycin (4 mg) and distilled water (1L). The agar agar for long-term storage contains rice flour $(15 \mathrm{~g})$, agar $(15 \mathrm{~g})$, sugar $(5 \mathrm{~g})$, streptomycin $(40 \mathrm{mg})$ and distilled water (1L). Micro-organisms produced in the Potato Dextrose Agar (PDA) environment contain potatoes $(200 \mathrm{~g})$, sugar $(20 \mathrm{~g})$, agar $(18 \mathrm{~g})$, streptomycin (40 mg) and distilled water (1L).

\section{Isolation of Pyricularia grisea fungus}

Isolation of P.grisea by methods previously used by Hayashi and Fukuta (2009). Blast samples were collected from wild rice, and single-celled strains were isolated from damaged leaf cells. Single-celled fungal spores were selected on agar and incubated for three days, which were then transferred to rice agar discs for further study.

\section{Enzyme protease activity}

Fungal strains cultured on Glucose Yeast Extract Peptone Agar (GYP) (1 g glucose, 0.1 g yeast extract, $0.5 \mathrm{~g}$ peptone, $16 \mathrm{~g}$ agar and $1 \mathrm{~L}$ distilled water) contained $0.4 \%$ gelatin at $\mathrm{pH} 6.0$ in a petri dish incubated in a dark room at $28^{\circ} \mathrm{C}$ to investigate the protease activity. Three plates with 3 replicates containing the fungus were used to measure the activity of the enzyme. Petri dishes were injected with $0.1 \mathrm{ml}$ of $0.1 \mathrm{M}$ ammonium sulfate and the apparent area was observed around the active 
colonies after six days of fungal growth, indicating the presence of protease enzymes (Prabavathy et al. 2013, Sunitha et al. 2013). The solution was then filtered and stored in a refrigerator at $4^{\circ} \mathrm{C}$ for later use. For quantitative testing, the protease activity was calculated by decomposing casein, 1 $\mathrm{ml}$ of the filtrate added to $1 \mathrm{ml}$ of $1 \% \mathrm{w} / \mathrm{v}$ casein $(\mathrm{pH} 7.5)$ and incubated for 1 hour at $45^{\circ} \mathrm{C}$. Next, the reaction was stopped by adding $3 \mathrm{ml}$ of $0.5 \mathrm{M}$ trichloroacetic acid (TCA). Next, the mixture was centrifuged at $5000 \mathrm{rpm}$ for 30 minutes, and the upper portion was measured at $275 \mathrm{~nm}$ using the HACH DR / 4000U spectrometer (HACH Company, Loveland, CO)., USA) (Patil et al. 2015). Tyrosine of varying concentrations $(10-100 \mu \mathrm{g} / \mathrm{mL})$ was used to establish the calibration curve. An enzyme activity unit is defined as the amount of enzyme required to release $1 \mu \mathrm{g}$ of tyrosine (Kunitz et al. 2015).

\section{Preparation of methanol extract}

Fresh leaves of Commelina communis L. were collected in Vietnam in September 2016. Dry leaves were extracted with methanol. The extraction of ten grams of leaf powder mixed with $100 \mathrm{~mL}$ of distilled water was shaken for 48 hours at room temperature. The extracts were then filtered, concentrated, dried and stored in a refrigerator at $4^{\circ} \mathrm{C}$ for future use (Kumar et al. 2016).

\section{Antifungal activity}

The method of extracting and screening mushroom activity was used from Toan et al. (2018) P. grisea was isolated on potato agar (PDA) at $28^{\circ} \mathrm{C} \pm 2{ }^{\circ} \mathrm{C}$. The five extractable levels were prepared as $0.1 \mathrm{mg} / \mathrm{mL} ; 0.5 \mathrm{mg} / \mathrm{mL} ; 1 \mathrm{mg} / \mathrm{mL} ; 5$ $\mathrm{mg} / \mathrm{mL}$ and $10 \mathrm{mg} / \mathrm{mL}$ with sterile distilled water. Vaccination of $1 \mathrm{~mL}$ of the extracted solution into $10 \mathrm{~mL}$ of PDA medium was poured onto a sterile
Petri dish, and then about $2 \mathrm{~mm}^{2}$ of the prepared fungi were placed in the middle of Petri dish. Transplanted plates were incubated at $28^{\circ} \mathrm{C} \pm 2{ }^{\circ} \mathrm{C}$ in a warm cabinet. For control samples, the fungus was implanted in distilled water. After three days of incubation, the colony diameter of the control and control plates were measured. The inhibition was calculated by the following equation: $\mathrm{I}=((\mathrm{C}-\mathrm{T}) /$ C) $\times 100 \%$, where (I) is the degree of inhibition (\%), $\mathrm{C}$ is the diameter of the control colonies, and $(\mathrm{T})$ is the diameter of the colonies of the treatments (Kartal et al. 2011). The concentration $(\mathrm{mg} / \mathrm{mL}$ ) required inhibiting the growth of $50 \%$ mycelium of $P$. grisea. Inhibition and corresponding levels of anti-fungal activity on $P$. grisea are shown in Table 1.

\section{Statistical analysis}

Standard errors and significance of enzyme activity were calculated using Mini-tab 16 software. Data comparing $\mathrm{P}<0.01$ are considered to be significantly different. The mean values were compared by the DUNCAN's multiple range test using SPSS statistics.

\section{RESULTS}

The three different isolates of $P$. grisea were isolated from wild rice (Oryza rufipogon) based on its susceptible response to monogenic

Table 1. Zone of inhibition and relative level of activity of resistance

\begin{tabular}{lc}
\hline $\begin{array}{l}\text { Zone of } \\
\text { inhibition }(\mathrm{mm})\end{array}$ & $\begin{array}{c}\text { Inhibition } \\
\text { activity level }\end{array}$ \\
\hline$>17$ & +++ , strong \\
$12-16$ &,++ moderate \\
$7-11$ & + , weak \\
$6-0$ &,- negative \\
\hline
\end{tabular}

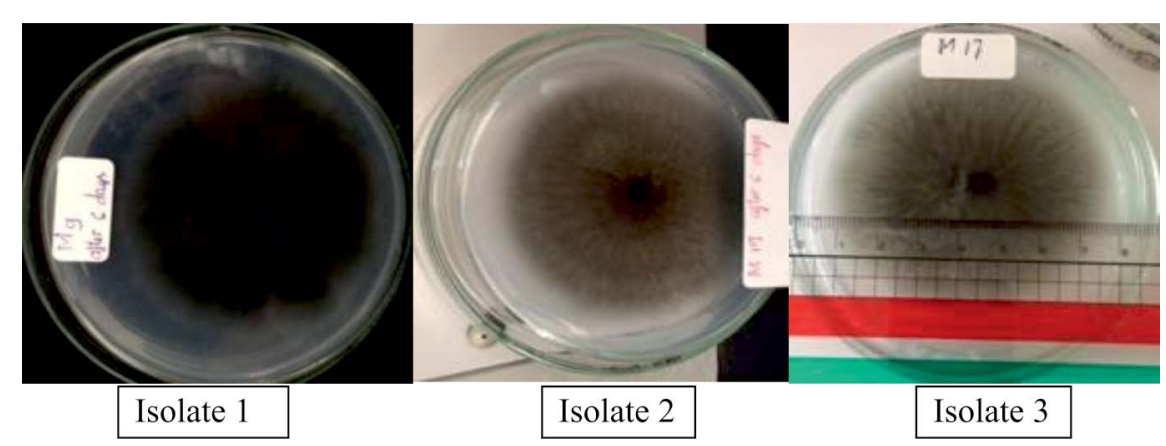

Fig. 1. Production of fungal enzyme of three isolates with GYP agar medium. 
rice lines (Hayashi et al. 2009). Designation of these isolated fungi species were presented in Table 2. There were two isolates in group " $U$ " that had one pathotype (U43) virulent to monogenic lines (Pit, LTH and Pia). Besides that, these isolates had pathotype "i4", which was virulent to (Pi5(t)).
While Isolates 1 and 3 had pathotype "z05", which were virulent to Piz and Piz-t. Especially one pathotype " $\mathrm{i} 0$ " belongs to Isolate 2 which means $\mathrm{Pii}, \mathrm{Pi3}$, and $\mathrm{Pi5}$ genes are resistant to blast in this group.

Table 2. Isolated designations of three fungus species from wild rice in the South of Vietnam

\begin{tabular}{lccl}
\hline No. & Region/ Ecosystem & Pathotype & Code \\
\hline 1 & Binh Phan, Cho Gao, Tien Giang & U43-i4-k024-z05-ta532 & Isolate 1 \\
2 & Ngai Tu, Tam Binh, Vinh Long & U12-i0-k101-z05-ta102 & Isolate 2 \\
3 & Ngai Tu, Tam Binh, Vinh Long & U43-i4-k141-z15-ta522 & Isolate 3 \\
\hline
\end{tabular}

\section{Assessment of protease activity}

The protease activity of three isolates were evaluated by the degradation of casein using GYP medium for a qualitative test of protease. As shown in Fig. 1, among the three isolates, isolate 3 and isolate 1 showed a large diameter of clear zone (Table 3). It was observed that isolate 3 had the highest density of mycelium on the surface after six days of incubation on the culture GYP medium, when compared to the others.

Table 3. The qualitative evaluation of the fungal protease activity on GYP medium

\begin{tabular}{ll}
\hline $\begin{array}{l}\text { Isolate } \\
\text { name }\end{array}$ & $\begin{array}{c}\text { Diameter of } \\
\text { clear zone }(\mathrm{cm})\end{array}$ \\
\hline Isolate 1 & $6.87 \mathrm{~b} \pm 0.12$ \\
Isolate 2 & $6.43 \mathrm{~b} \pm 0.06$ \\
Isolate 3 & $7.67 \mathrm{a} \pm 0.29$
\end{tabular}

Values with similar letters are not significantly different for each variable, significant at $p<0.01 ; \pm$ values indicate standard errors of the means.
The objective of the present investigation was to select the fungal isolates with a high level of protease producing ability. The three isolates were checked for the quantitative test of extracellular protease in the GYP medium. Table 4 clearly shows that all isolates secreted protease enzyme at varied levels. The maximum protease activity 30.11 (U/ $\mathrm{ml}$ ) was accomplished after six days by isolate 3 . The lowest protease enzyme activity was observed by isolate 2 with enzyme activity $(12.810 \mathrm{U} / \mathrm{ml})$.

Table 4. Protease activity from different isolates in production medium

\begin{tabular}{lc}
\hline $\begin{array}{l}\text { Isolate } \\
\text { name }\end{array}$ & $\begin{array}{c}\text { Enzyme } \\
\text { activity (Unit/ml) }\end{array}$ \\
\hline Isolate 1 & $20.27 \mathrm{~b} \pm 1.88$ \\
Isolate 2 & $12.81 \mathrm{~b} \pm 1.72$ \\
Isolate 3 & $30.11 \mathrm{a} \pm 6.20$
\end{tabular}

Values in the columns with similar letters are not significantly different for each variable, significant at $p<0.01 ; \pm$ values indicate standard errors of the means.

Table 5. Inhibitory activity of day flower leaf extract on mycelial growth $(\mathrm{mm})$

\begin{tabular}{lcccccc}
\hline & \multicolumn{7}{c}{ Isolates } \\
\cline { 2 - 6 } $\begin{array}{l}\text { Concen. } \\
(\mathrm{mg} / \mathrm{mL})\end{array}$ & Isolate 1 & $\begin{array}{c}\text { Inhibition } \\
\text { activity } \\
\text { level }\end{array}$ & Isolate 2 & $\begin{array}{c}\text { Inhibition } \\
\text { activity } \\
\text { level }\end{array}$ & $\begin{array}{c}\text { Inhibition } \\
\text { Ictivity } \\
\text { Ievel }\end{array}$ \\
\hline 0.1 & $9.00 \mathrm{hi}$ & $(+)$ & $26.00 \mathrm{~b}$ & $(+++)$ & $16.33 \mathrm{fg}$ & $(++)$ \\
0.5 & $14.67 \mathrm{fg}$ & $(++)$ & $22.00 \mathrm{~cd}$ & $(+++)$ & $21 \mathrm{de}$ & $(+++)$ \\
1 & $16.67 \mathrm{ef}$ & $(++)$ & $19.00 \mathrm{def}$ & $(+++)$ & $8.67 \mathrm{i}$ & $(+)$ \\
5 & $9.67 \mathrm{hi}$ & $(+)$ & $21.33 \mathrm{~cd}$ & $(+++)$ & $13.67 \mathrm{gh}$ & $(++)$ \\
10 & $16.33 \mathrm{ef}$ & $(+++)$ & $29.67 \mathrm{a}$ & $(+++)$ & $25.33 \mathrm{bc}$ & $(+++)$ \\
\hline
\end{tabular}

+++ Strong ++: Moderate; +: Weak. Means were the diameter of the mycelial growth $(\mathrm{mm})$ of $P$. grisea. Means with similar letters are not significantly different at $p<0.01$. 

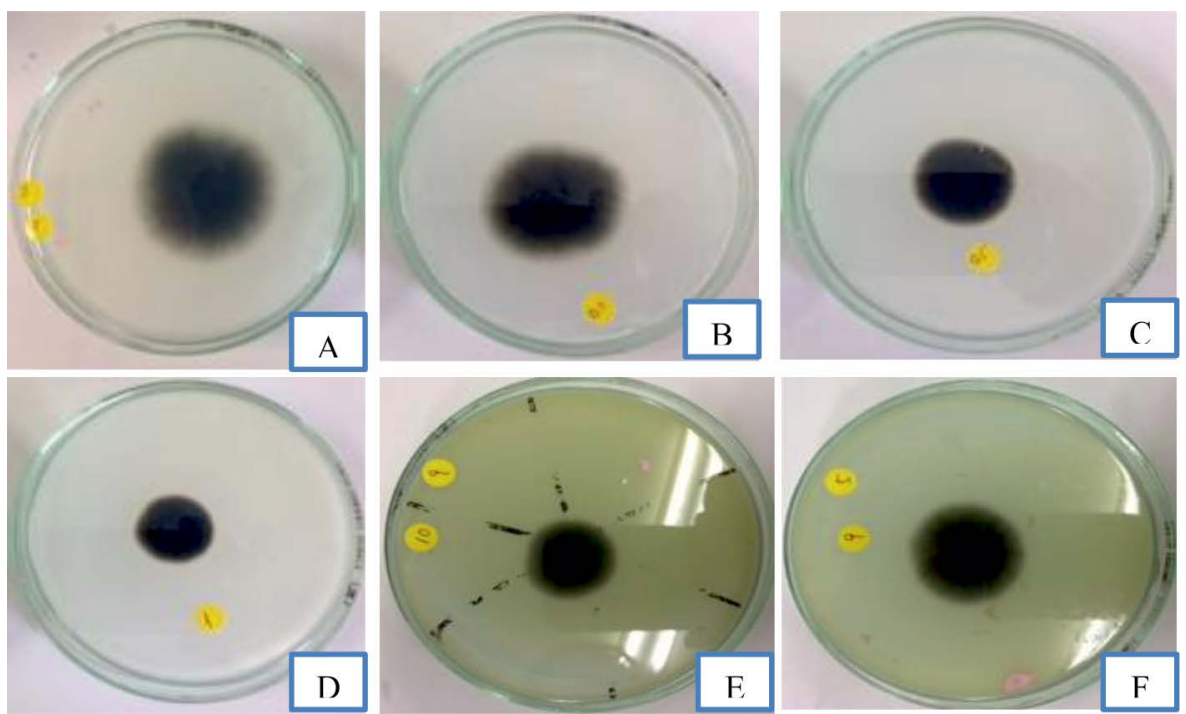

Fig. 2. Mycelia growth of Isolate 1 of P.grisea in response to control (A), $0.1 \mathrm{mg} / \mathrm{mL}$ (B), $0.5 \mathrm{mg} / \mathrm{mL}(C), 1 \mathrm{mg} / \mathrm{mL}$ (D), $5 \mathrm{mg} / \mathrm{mL}$ (E) and $10 \mathrm{mg} / \mathrm{mL}(\mathrm{F})$, repetitively of Commela communis L. extract on PDA medium.
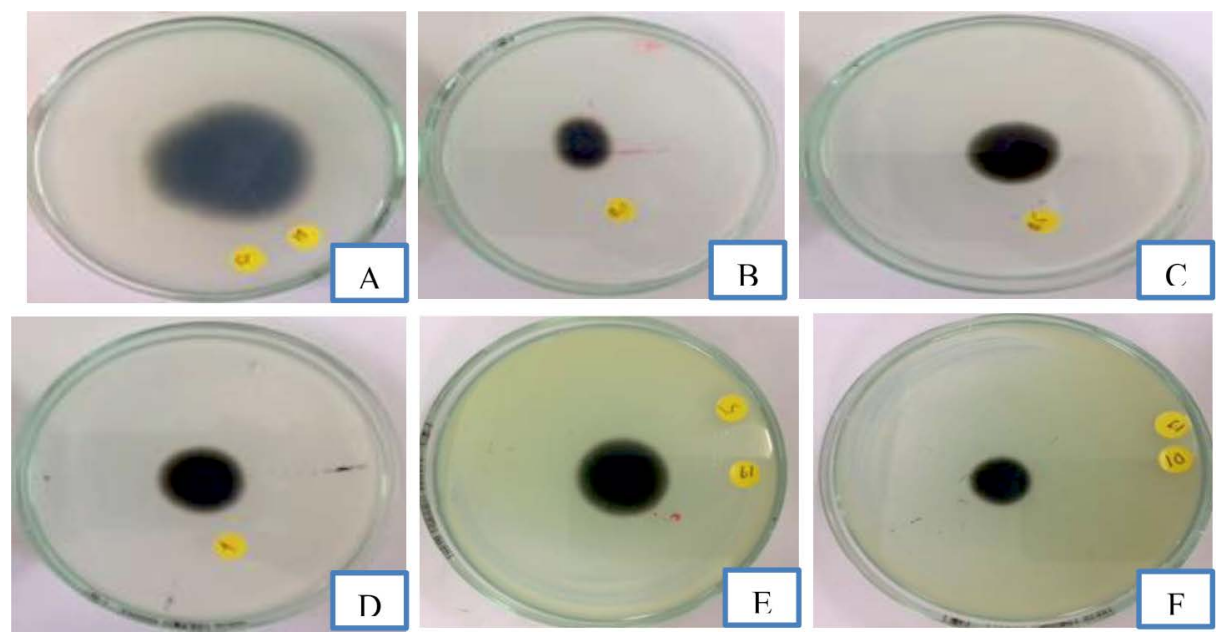

Fig. 3. Mycelia growth of Isolate 2 of P.grisea in response to control (A), $0.1 \mathrm{mg} / \mathrm{mL}$ (B), $0.5 \mathrm{mg} / \mathrm{mL}(C), 1 \mathrm{mg} / \mathrm{mL}$ (D), $5 \mathrm{mg} / \mathrm{mL}(\mathrm{E})$ and $10 \mathrm{mg} / \mathrm{mL}(\mathrm{F})$, respectively of Commela communis L. extract on PDA medium.

\section{Antifungal activity}

The antifungal inhibitory properties of methanol extract from Commelina communis $\mathrm{L}$. were tested on P.grisea (Table 5; Figs. 2-4). At the highest concentration $(10 \mathrm{mg} / \mathrm{mL})$, the extract showed the strongest fungus inhibition. Following were $0.5 \mathrm{mg} / \mathrm{mL}$ and $0.1 \mathrm{mg} / \mathrm{mL}$ showing moderate inhibition. And finally, the extract at $1-5 \mathrm{mg} / \mathrm{mL}$ had the lowest results. Based on the objective of the study, selecting a $10 \mathrm{mg} / \mathrm{mL}$ concentration was used to observe the effects on the methanol extract from the day flower inhibition on mycelial growth of P.grisea.
For the methanol extract, complete inhibition was found at the lowest IC $\mathrm{C}_{50}$ value (2.35 $\mathrm{mg} / \mathrm{mL}$ ) by isolate 2 followed by isolate $3(11.98$ $\mathrm{mg} / \mathrm{mL}$ ) (Table 6). The above values show that fungal growth of these isolates were inhibited.

\section{DISCUSSION}

In the present study, an investigation was made to isolate the protease enzyme from wild rice collected from different isolates. Fungi are an important component of rice microbiota occurring in natural habitats and change with 

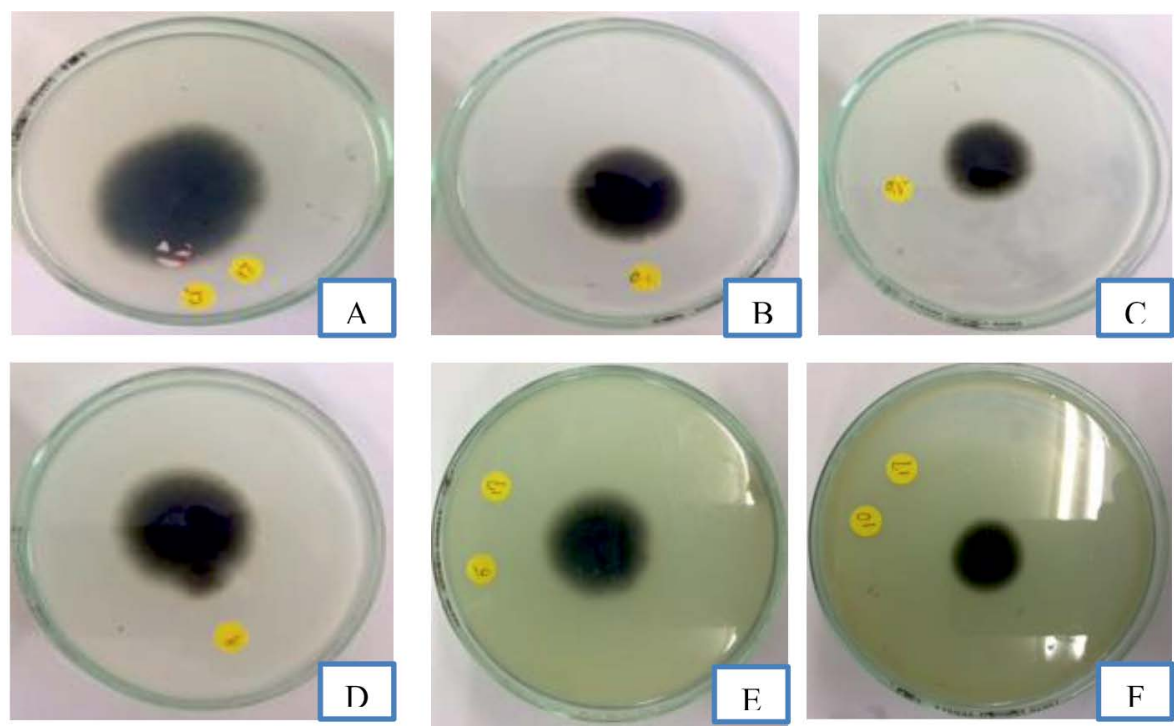

Fig. 4. Mycelia growth of Isolate 2 of P.grisea in response to control (A), $0.1 \mathrm{mg} / \mathrm{mL}$ (B), $0.5 \mathrm{mg} / \mathrm{mL}$ (C), $1 \mathrm{mg} / \mathrm{mL}$ (D), $5 \mathrm{mg} / \mathrm{mL}(\mathrm{E})$ and $10 \mathrm{mg} / \mathrm{mL}(\mathrm{F})$, respectively of Commela communis L. extract on PDA medium.

Table 6. Effect of methanol extract of day flower to different isolates

\begin{tabular}{lc}
\hline Isolates & $\mathrm{IC}_{50}(\mathrm{mg} / \mathrm{mL})$ \\
\hline Isolate 1 & $41.34 \mathrm{a}$ \\
Isolate 2 & $2.35 \mathrm{c}$ \\
Isolate 3 & 11.98 \\
\hline
\end{tabular}

$\mathrm{IC}_{50}(\mathrm{mg} / \mathrm{mL})$ is the concentration required to inhibit $50 \%$ mycelial growth of P.grisea. Means with different letters are significantly different at $p<0.01$.

different environmental conditions. They can be used to characterize differences among strains of various host plants or to assay for production of enzymes with various industrial applications. There is a growing need for new, environmentally friendly antimicrobial agents that may be used safely to control plant pathogens (Capdeville et al. 2007). Extracellular protease is important for the hydrolysis of proteins in cell-free environments (Kalisz et al. 1998). It reported in a few fungal plant pathogens and it is clear that protease produced by pathogenic fungus plays an important role in the host plant, providing nitrogenous compounds during infection of the fungus (Archetr et al. 1997).

Protease is widely distributed among microorganisms including fungi, bacteria, and actinomycetes (Ma 2013). Among fungi genera, Aspergillus, Penicillium, Paecilomyces, Rhizopus and Rhizomucor are well-known producers of proteases (Devi 2008, Sindhu et al. 2009, Krishna 2009). Patil et al. (2015) reported that nine different fungi concluding Cladosporium sp., Rhizoctonia sp., Aspergillus sp., Chaetomium sp., Biosporus sp., Fusarium sp., Curvularia sp., Cladosporium sp., and Colletotrichum sp. were isolated from seven medicinal plants. Out of the nine fungi screened, the productivity of protease was the highest in Biosporus sp. $(11 \mathrm{U} / \mathrm{ml})$. There fungal isolates in this study had protease activity higher than that of Biosporus sp. Among the tested isolates, Isolate 3 showed the highest protease enzyme productivity $(30.11 \mathrm{U} / \mathrm{ml}$ ) (Table 4$)$. The present study indicated three isolates might produce a high amount (high activity) of protease enzyme. Although the blast isolates from wild rice are limited, there have been few studies reported on protease enzyme from new sources of $P$. grisea from wild rice (Oryza rufipogon) up to the present. The current study opened up the way for wide openings in proteolytic fungal research tending towards the development of resistance in infectious micro-organisms by determining important characterization in agriculture and other industries. Further detailed study on the other enzymes from the available fungus is characterized by examining their sensitivity to specific protease inhibitors to obtain clear results. 
Rice blast is one of the most serious diseases affecting rice and is caused by a highly variable fungal pathogen $P$. grisea, which severely affects the rice yield (Khush et al. 2009). This disease occurs in much rice growing areas worldwide (Moffat 1994; IRRI 2010). Management of this disease has been focused on the use of synthetic chemicals and resistant cultivates. However, the plant extract was more potent and environmentally friendly compared with synthetic fungicides (Gangawane 1990).

Previous studies showed the aqueous extract of Coffee arabica inhibitions on P.grisea (Hubert et al. 2015). The Piper caninum Blume crude extract had a very strong effect against P.oryzae (Suriani et al. 2015). The chemicals identified by GC-MS in the methanol extract were mostly from the bamboo leaf. But they were inactive on the growth of P.grisa with all concentrations (Toan et al. 2018). In this experiment, P.grisea was inhibited by methanol extract (Table 5). With different concentrations of methanol extract, the diameters of growth and spore production could be significantly reduced in isolate 2 . While isolate 1 and isolate 3 were dependant on different concentrations that created different inhibition ability (Table 5). IC50 $(\mathrm{mg} / \mathrm{mL})$ is concentration required to inhibit $50 \%$ mycelial growth of P.grisea. Through the IC50 value, isolate 2 showed that only a small amount of extract could be inhibited (IC50 $=2.35 \mathrm{mg} / \mathrm{mL}$ ) and isolate 1 needed the highest amount of extract (IC50 $=41.34 \mathrm{mg} / \mathrm{mL})$. The dayflower leaf extract has shown significant inhibition against P.grisea. Although methanol extract from the dayflower inhibited on P.grisea. However, it was still a crude extract and had many impurities. The next study will analyze and identify the chemical components in the extract more clearly.

\section{CONCLUSION}

The findings of this study highlighted that three isolates from wild rice were collected based on a designation of new international standard. It would be interesting to characterize the enzyme protease activity and established the active inhibition of the dayflower leaf existing source to manage the affection of $P$. grisea in rice.

\section{ACKNOWLEDGMENTS}

We thank IRRI for providing the resistance gene materials for this study and appreciate Do Tan Khang for his assistance in preparing this manuscript.

\section{CONFLICTS OF INTEREST}

conflict of interest.

The authors declare that there is no

\section{AUTHORS' CONTRIBUTION}

All authors have made substantial, direct and intellectual contribution to the work and approved it for publication.

\section{FUNDING}

None.

\section{DATA AVAILABILITY}

All datasets generated or analyzed during this study are included in the manuscript.

\section{ETHICS STATEMENT}

This article does not contain any studies with human participants or animals performed by any of the authors.

\section{REFERENCES}

1. Archer DB, Peberdy JF. The molecular biology of secreted enzyme production by fungi. Critical Rev. Biotechnol, 1997; 17: 273-306. https://doi.org/10.3109/07388559709146616.

2. Bhat SV, Wathi BR, Rosy M, Govindappa M. Isolation and characterization of Glucose Oxidase (GOD) from Aspergillus flavus and Penicillium sp. Int. J. of Curr. Microb. and App. Sci., 2013; 2:153-161.

3. Capdeville G, Souza MTJR, Santos JRP, Paula MS, et al. Selection and testing of epiphytic yeasts to control anthacnose in post-harvest of papaya fruit. Scientia Horticulture, 2007; 111: 179-85. https://doi.org/10.1016/j.scienta.2006.10.003.

4. Chen $H$, Hayn M, Esterbauer $H$. Three forms of cellobiohydrolase I from Trichoderma reesei. Biochemical Molecular Biology, 1993; 30: 901-910.

5. Devi MK. Purification, characterization of alkaline protease enzyme from native isolates Aspergillus niger and its compatibility with commercial detergents. Indian Journal Science Technology, 2008; 1: 1-6.

6. Fei-Hong Bing JL, LiZ, Zhang GB, Liao YF, Li J, Dong CY. Antiinfluenza-virus activity of total alkaloids from Commelina communis L. Archives of Virolog, 2009; 154: 1837. https://doi.org/10.1007/s00705-009-0503-9.

7. Gangawane LV. Fungicide resistance in plant pathogens in India. Indian Phytopathology, 1990; 40: 551-553. 
8. Hanan HA. Isolation and screening of extracellular proteases produced by new isolated Bacillus sp. Journal Applied Pharmacy, 2012; 2: 071-074.

9. Hayashi N, Fukuta Y. Proposal for a new international system of differentiating races of blast (Pyriculariapryxae Cavara) using LTH monogenic lines in rice (Oryza sativa L.) JIRCAS working report No. 63, Tsukuba city, Ibaraki prefecture Japan. Japan International Research Center for Agricultural Science, 2009; 11-15.

10. Hubert J, Mabagala R, Mamiro D. Extract against Pyricularia grisea, Causal agent of rice blast disease. American Journal of Plant Sciences, 2015; 6: 602-611. https://doi.org/10.4236/ajps.2015.65065.

11. IRRI. Anaporthe grisea Rice blast http://www. metapathogen.com.visisted, 2010.

12. Kamalakannan A, Shanmugan V, Suhendran S, Srinivasan R. Antifungal properties of plant extracts against Pyriclaria oryzae, rice blast pathogen. Indian Phytopathol., 2001; 54: 490-492.

13. Khan MA, Ahmad N, Zafar AU, Nasir IA, Qadir MA. Isolation and screening of alkaline protease producing bacteria and physio-chemical characterization of the enzyme. Africa Journal Biotechnology, 2011; 10: 6203-6212.

14. Kalisz MH. Microbial proteinases. Advance Biochemical Engineering Biotechnology, 1998; 36: 17-55.

15. Kartal SN,Terzi E, Kose C, Hofmeyr J, Imamura Y. Efficacy of tar oil recovered during slow pyrolysis of macadamia nut shells. International Biodeterioration and Biodegradation, 2011; 65: 369-373. https://doi.org/10.1016/j.ibiod.2010.08.011.

16. Khush GS, Jena KK. Status and future prospects for research on blast resistance in rice (Oryza sativa L.). In Advances in Genetics, Genomics and Control of Rice Blast Disease, 2009; 1-10. https://doi.org/10.1007/978-1-4020-9500-9_1.

17. Krishna KV. Optimization of growth and production of protease by Penicillium species using submerged fermentation. International Journal of Microbiology Research, 2009; 1: 14-18.

18. Kumar NS, Simon N. In vitro anti antibacterial activity and phytochemical analysis of Gliricidia sepium L. leaf extracts. Journal of Pharmacognosy and Phytochemistry, 2016; 5: 131-133.

19. Kunitz N. Methods of enzymatic analysis 2 nd ed. Velag, Chenie. Acad. Press N.Y. London, 2015; 807-814.

20. Ma L. Kinetic studies on batch cultivation of Trichoderma reesei and application to enhance cellulase production by fed-batch fermentation. Journal Biotechnology, 2013; 166: 192-197. https://doi.org/10.1016/j.jbiotec.2013.04.023.

21. Moffat AS. Mapping the sequence of disease resistance. Science, 1994; 265: 1804-1805. https://doi.org/10.1126/science.8091208.

22. Netam RS, Bahadur NS, Tiwari U, Tiwari RKS. Efficacy of plant extracts for the control of (Pyricularia grisea) blast of rice under field condition of Bastar, Chhattisgarh. Research Journal of Agriculture, 2011; 2: 269-271.

23. Olufolaji DB, Adeosun BO, Onasanya RO. In vitro investigation on antifungal activity of some plant extracts against Pyricularia oryzae. Nigeria Journal Biotechnology, 2015; 29: 38-43. https://doi.org/10.4314/njb.v29i1.6.

24. Patil MG, Pagare J, Patil SN, Sidhu AK. Extracellular enzymatic activities of endophytic fungi isolated from various medicinal plants. International Journal of Current Microbiology and Applied Sciences, 2015; 4: 1035-1042.

25. Portumarthi R, Subhakar C, Jetty A. Alkaline protease production by submerged fermentation in stirred tank reactor using Bacillus licheniformis NCIM 2042: Effect of aeration and agitation regismesm. Biochemical Engineering Journal, 2017; 34: 185-192. https://doi.org/10.1016/j.bej.2006.12.003.

26. Prabavathy D, Nachiyar CV. Screening the bioactivity of ethyl acetate extract of endophytic Phoma sp isolated from Vitex negundo". International conference on chemical and Environmental Engineering, 2013; 15-16.

27. Sena APA, Amanda A, Chaibub VC, Marcio et al. Increased enzymatic activity in rice leaf blast suppression by crude extract of Epicoccum sp. Tropical Plant Pathology, 2013; 38: 387-397. https://doi.org/10.1590/S1982-56762013005000028.

28. Shakil A, Zunara Z, Azeem H, Hamid M. Isolation and screening of protease producing bacterial species. Mycopath, 2012; 1: 51-54.

29. Shibano M, Kakutani K, Taniguchi M, Yasuda M, Baba $K$. Antioxiant constituents in the dayflower (Commelina communis L.) and their $\beta$ - glucosidase - inhibitory activity. Journal of Natural Medicines, 2008; 62: 349. https://doi.org/10.1007/s11418-008-0244-1.

30. Sindhu R, Suprabha GN, Shashidhar S. Optimization of process parameters for the production of alkaline protease from Penicillium godlewskii SBSS 25 and its application in detergent industry. African of Journal Microbiology Research, 2009; 3: 515-522.

31. Sunitha VH, Aevi DN, Srinvinvas C. Extracellular enzymatic activity of endophytic fungal strains isolated from medicine plants. Word Journal of Agriculture, 2013; 9: 01-09.

32. Suriani NL, Suprata DN, Sudana IM, Temaja IGRM. Antifungal activity of piper canium against Pyricularia oryzae Cav. the cause of rice blast disease on rice. Journal of Biology, Agriculture and Healthcare, 2015; 2224-3208.

33. Toan NP, Xuan TD, Ha PTT, Anh TTT, Khanh TD. Inhibitory effects of bamboo leaf on the growth of Pyricularia grisea fungus. Agriculture, 2018; 8: 92. https://doi.org/10.3390/agriculture8070092. 